\title{
Recycling Zr-Nb-Sn-Fe Scrap in Casting of Nuclear-Grade Alloy Ingots and Its Effects on Mechanical Performance and Integrity
}

\author{
Jae Sook Song and Sun Ig Hong
}

\begin{abstract}
Recycling of Zr-Nb-Sn-Fe scraps in casting enhances the price competitiveness of nuclear-grade $\mathrm{Zr}$ alloys and accordingly the energy from nuclear power plants. Increasing the fraction of scrap in casting of new alloy ingots increases the price competitiveness, but it aggravates the deformability and mechanical reliability of cast alloys. In this study, the effect of scrap ratio on the mechanical reliability of $\mathrm{Zr}-\mathrm{Nb}$-Sn-Fe alloys was studied. The increase of scrap fraction in casting increases the oxygen content in the ingot and nuclear claddings fabricated from cast ingots. The increase of oxygen content is caused by the surface oxide of scraps such as small pieces of turning, chips, etc. Iron content was not found to increase appreciably with the increasing fraction of scrap because scraps were well kept in the iron-free container. The microstructure of ss-cast $\mathrm{Zr}$ alloy with increasing fraction of scraps displayed plate/or needle $\alpha$ phase and the microstructural features were observed to be affected by increase of scrap fraction. The strength increases with increasing fraction of scrap, which can be attributed to the increase of oxygen content. The ductility decreased slightly with increase of scrap fraction. The strength increased at the expense of ductility with increase of scrap fraction. In some ingots, iron oxide flakes were intentionally added to explore the effects of iron oxide which may be added from the scarp storage container. The alloys with the addition of iron oxide flakes exhibited the drastic decrease of the formability and exhibited the brittle fracture behavior during rolling. The increase of oxide fraction increased the oxidation resistance because of high oxygen content the matrix may have prevented oxygen diffusion into matrix.
\end{abstract}

Index Terms-Zr-Nb-Sn-Fe, scrap, recycling, nuclear energy, oxygen, ductility.

\section{INTRODUCTION}

In the nuclear energy industry, components and parts made of nuclear-grade zirconium based alloys are allowed and employed in the fabrication of fuel assemblies used in the design and construction of the vast majority of currently operating nuclear reactors and those under construction, and planned around the world [1]. The number of nuclear power reactors increases to varying degrees in many countries all

Manuscript received September 20, 2019; revised December 15, 2019. This research was supported by the Future Material Discovery Program of the National Research Foundation of Korea (NRF) funded by the Ministry of Science, ICT and Future Planning (MSIP) of Korea(2016M3D1A1023532).

Jae Sook Song is with Nano Engineering Research Cener, Chungnam National University, Daejon 34134, South Korea (e-mail: jsongdoctor@hanmail.net).

Sun Ig Hong is with Materials Science and Engineering Department, Chungnam National University, Daejon 34134, South Korea (e-mail: sihong@cnu.ac.kr). over the world. And the ways to lower the costs of nuclear-grade $\mathrm{Zr}$ alloys have been explored and some problems regarding the international supply chain of nuclear fuel materials and components have surfaced. The supply of price-competitive nuclear-grade zirconium alloys coupled with scrap recycling to enhance the price-competitiveness over other energy sources needs to be evaluated with high level of the scrutiny.

Recycling provides environmental benefits in terms of energy savings, reduced volumes of waste, and reduced emissions associated with energy savings and a significant factor in the supply of many of the metals used in our society [2]. Recycling practices and the description of those practices vary substantially among the metal industries. Generally, scrap is categorized as "new" or "old," where "new" indicates pre-consumer sources, and "old" suggests postconsumer sources. The many stages of industrial processing that precede an end-product are the sources of new scrap. Zirconium scrap composes about $30 \%$ to $35 \%$ of the feedstock for ingot production [1]. New scrap is generated during the melting, forging, rolling, casting, and fabrication of zirconium components. In addition, small quantities of obsolete or old scrap are recycled from dismantled process equipment, vessels, and heat exchangers. Although no data are available as to the percentage breakdown of sources of scrap, it is estimated that less than $2 \%$ of ingot production is derived from old scrap.

Prior to melting, scrap must be analyzed, classified, and processed to remove impurities [1] to ensure the materials performance reliability after recycling. Several companies have proprietary processes to accomplish this task to minimize the possible contamination. Scrap is initially melted without virgin metal by some nuclear-grade zirconium ingot producers, using vacuum-arc-reduction melting practices. The scrap zirconium is blended with new zirconium metal produced from the processing of the zirconium silicate mineral, zircon. The supply of nuclear-grade zirconium alloys coupled with scrap recycling to enhance the price-competitiveness over other energy sources needs to be evaluated for the growth of nuclear energy industry. In order to ensure the price competitiveness, scrap from nuclear-grade $\mathrm{Zr}$ alloys and components should be mixed with the new nuclear-grade $\mathrm{Zr}$ sponge for arc melting. $\mathrm{Zr}-\mathrm{Nb}-\mathrm{Sn}-\mathrm{Fe}$ are of the most advanced and reliable nuclear cladding alloys [3]-[10] in the nuclear industry. In this study, the effect of scrap ratio on the mechanical and corrosion properties of $\mathrm{Zr}-1 \mathrm{Nb}-0.7 \mathrm{Sn}-0.1 \mathrm{Fe}$ alloy was studied. 


\section{EXPERIMENTAL}

Collected $\mathrm{Zr}$ alloy turnings, chips and pieces left from machining and manufacturing $\mathrm{Zr}-1 \mathrm{Nb}-0.7 \mathrm{Sn}-0.1 \mathrm{Fe}$ tubes and parts were cleaned by alchohol, acetone and acid to remove greases, oils, dirt and oxide films. New $\mathrm{Zr}-1 \mathrm{Nb}-0.7 \mathrm{Sn}-0.1 \mathrm{Fe}$ alloy ingots were cast by vacuum arc melting the cake-shaped mixture of pieces of scrap and sponge with scrap:sponge ratio of $1: 9,3: 7,5: 5$ and $7: 3$. Since scrap was formed during machining and manufacturing parts, it is more likely to be coated by oxide, they are likely to have more oxide films because of heating during machining and a large surface to volume ratio. In Table I, target alloy compositions and scarp: sponge ratio used for casting is summarized. Oxide contamination of scrap may increase the oxide content in newly cast alloy after remelting, which may deteriorate the properties. Some scrap cake was mixed with $\mathrm{Fe}_{2} \mathrm{O}_{3}$ particle to investigate the possible inclusion of iron oxide from steel storage containers during storage and handling of scrap [11]. In order to investigate the possible effects of impurities introduced from the scrap, some model alloys without scrap addition were cast with the intentional addition $\mathrm{Fe}$ and $\mathrm{Fe}_{2} \mathrm{O}_{3}$ to simulate and examine the most probable impurities of $\mathrm{Fe}$ and $\mathrm{O}$. In Table II, the chemical compositions of model alloy with intentional addition of $\mathrm{Fe}$ and $\mathrm{Fe}_{2} \mathrm{O}_{3}$ in the present study are summarized.

TABLE I: TARGET COMPOSITION AND ZR SCRAP: ZR SPONGE RATIOS FOR ZR ALLOYS IN THIS STUDY

\begin{tabular}{lcc}
\hline \hline & & \\
& scrap:sponge ratio & scrap \\
\hline Zr-1Nb-1Sn-0.1Fe & $10: 90$ & \\
\hline & & ZIRLO \\
\hline Zr-1Nb-1Sn-0.1Fe & $30: 70$ & ZIRLO \\
\hline Zr-1Nb-1Sn-0.1Fe & $50: 50$ & ZIRLO \\
\hline & & \\
Zr-1Nb-1Sn-0.1Fe & $70: 30$ & ZIRLO \\
\hline Zr-1Nb-0.7Sn-0.1Fe & $10: 90$ & ZIRLO \\
\hline Zr-1Nb-0.7Sn-0.1Fe & $30: 70$ & ZIRLO \\
\hline Zr-1Nb-0.7Sn-0.1Fe & $50: 50$ & ZIRLO \\
\hline Zr-1Nb-0.7Sn-0.1Fe & $70: 30$ & ZIRLO \\
\hline \hline
\end{tabular}

TABLE II: CHEMICAL COMPOSITION OF MODEL ALLOYS WITH INTENTIONAL ADDITION OF FE AND $\mathrm{FE}_{2} \mathrm{O}_{3}(\mathrm{WT} \%)$

\begin{tabular}{lllll}
\hline \hline Ingot number & $\mathrm{Zr}$ & $\mathrm{Nb}$ & $\mathrm{Fe}$ & $\mathrm{Fe}_{2} \mathrm{O}_{3}$ \\
\hline 1 & bal. & 1.2 & 0.2 & \\
\hline 2 & bal. & 1.2 & 0.3 & \\
\hline 3 & bal. & 1.2 & & 0.28 \\
\hline 4 & bal. & 1.2 & & 0.43 \\
\hline \hline
\end{tabular}

The mixture of scrap and sponge pieces was compacted into scrap cake using a high-pressure press at room temperature. The scrap cake was mixed with $\mathrm{Zr}$ sponge and other alloying elements before being pressed. The ingot cakes were annealed, $\beta$-quenched (from $1095{ }^{\circ} \mathrm{C}$ to water maintained at room temperature), hot-rolled at $580{ }^{\circ} \mathrm{C}$ annealed at $600{ }^{\circ} \mathrm{C}$ and cold-rolled with an intermediate heat treatment at $600{ }^{\circ} \mathrm{C}$. Cold-rolled specimens cut parallel to the rolling axis tensile-tested using a united testing machine (SFP 10). Oxidation tests were carried out in a chamber with de-mineralized water at $400{ }^{\circ} \mathrm{C}$ under the pressure of 103 bar for 15 days.

\section{RESUlT AND DisCUSSION}

Fig. 1(a) and 1(b) display the typical shape of compressed $\mathrm{Zr}$ sponge-scrap cake (a) and ingot cake(b) prepared in this study. Impurity contents of four $\mathrm{Zr}-1 \mathrm{Nb}-0.7 \mathrm{Sn}-0.1 \mathrm{Fe}$ alloys are summarized in Table. I. As shown in Table I, the oxygen content in the ingot cake increased rapidly with increasing fraction of scrap. The increase of oxygen content can be attributed to the surface oxide of scrap cake made of small pieces of turning, chips, etc. Iron contents in the ingot with the addition of $\mathrm{Fe}_{2} \mathrm{O}_{3}$ particles increased appreciably, suggesting the reduction of $\mathrm{Fe}_{2} \mathrm{O}_{3}$ by $\mathrm{Zr}$ and dissolution of oxygen and iron into the matrix. Contents of alloying elements and oxygen in each ingot are summarized in Table III.

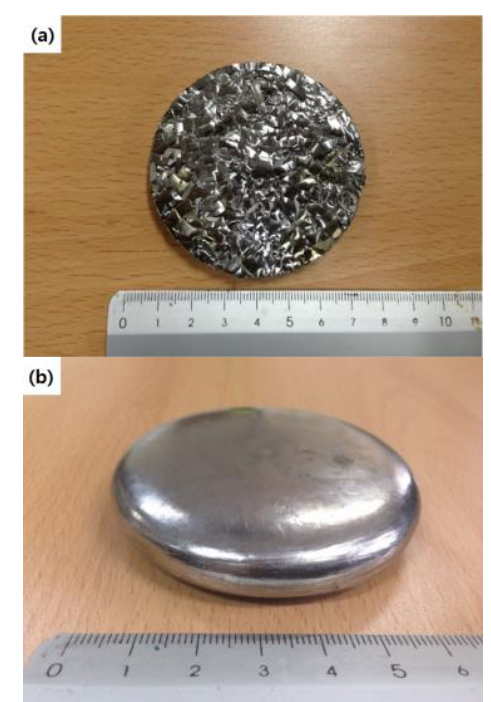

Fig. 1. Typical shape of compressed $\mathrm{Zr}$ sponge-scrap mixture cake (a) and ingot cake(b) prepared in this study.

TABLE III: CHEMICAL COMPOSITION OF SPECIMENS, WT\% (*MG/G)

\begin{tabular}{lllll}
\hline \hline & $\mathrm{Zr}$ & $\mathrm{Nb}$ & $\mathrm{Fe}$ & $\mathrm{O}(\mathrm{ppm})$ \\
\hline $\mathrm{Zr}-1.2 \mathrm{Nb}-0.2 \mathrm{Fe}$ & Bal. & 1.20 & 0.212 & $* 1090$ \\
\hline $\mathrm{Zr}-1.2 \mathrm{Nb}-0.3 \mathrm{Fe}$ & Bal. & 1.21 & 0.298 & $* 1283$ \\
\hline $\mathrm{Zr}-1.2 \mathrm{Nb}-0.28 \mathrm{Fe} 2 \mathrm{O} 3$ & Bal. & 1.21 & 0.251 & $* 1996$ \\
\hline $\mathrm{Zr}-1.2 \mathrm{Nb}-0.43 \mathrm{Fe} 2 \mathrm{O} 3$ & Bal. & 1.21 & 0.332 & $* 3157$ \\
\hline \hline
\end{tabular}

Fig. 2 shows the as-cast structure of $\mathrm{Zr}-1.2 \mathrm{Nb}-0.2 \mathrm{Fe}$ (a), $\mathrm{Zr}-1.2 \mathrm{Nb}-0.3 \mathrm{Fe} \quad$ (b), $\mathrm{Zr}-1.2 \mathrm{Nb}-0.28 \mathrm{Fe}_{2} \mathrm{O}_{3} \quad$ (c), $\mathrm{Zr}-1.2 \mathrm{Nb}-0.43 \mathrm{Fe}_{2} \mathrm{O}_{3}$ (d) cast with the intentional addition of $\mathrm{Fe}$ or $\mathrm{Fe}_{2} \mathrm{O}_{3}$. In alloys with intentional $\mathrm{Fe}$ addition, plate-shaped $\alpha$ phase was observed whereas needle-shaped $\alpha$ phase was observed in alloys with $\mathrm{Fe}_{2} \mathrm{O}_{3}$ addition. The thickness of plate-shaped $\alpha$ phase in alloys with Fe addition was $8-10 \mu \mathrm{m}$ whereas the thickness of needle-shaped $\alpha$ phase 
in alloys with $\mathrm{Fe}_{2} \mathrm{O}_{3}$ addition was observed to be 2-3 $\mu \mathrm{m}$. The change of shapes of $\alpha$ phase is likely to be associated with the oxygen content in the alloys. The oxygen contents in alloys with $\mathrm{Fe}$ addition was $1000-1300 \mathrm{ppm}$ and those in alloys with $\mathrm{Fe}_{2} \mathrm{O}_{3}$ addition was 1990 3200ppm as shown in Table III. The thickness of needle-shaped $\alpha$ phase also decreased with increase of oxygen content as shown in Fig. 1(c) and 1(d). The addition oxygen is known to increase the stability of hexagonal $\alpha$ phase, causing the reduction of the thickness due to enhanced nucleation of $\alpha$ phase [8]-[10]. Interstitial atoms such as oxygen [8]-[10] and carbon [11], [12] are known to increase the strength of $\mathrm{Ti}$ and $\mathrm{Zr}$, but it decreases the deformability and ductility if the oxygen content exceeds 1800 ppm [13]-[15].

In order to evaluate the effect of impurities on the hardness of ingots, the microhardness of ingots with $\mathrm{Fe}$ or $\mathrm{Fe}_{2} \mathrm{O}_{3}$ was measured and summarized in Table IV. The hardness values were measured to be $153.1 \mathrm{Hv}$ and $167.8 \mathrm{Hv}$ for $\mathrm{Zr}-1.2 \mathrm{Nb}-0.2 \mathrm{Fe}$ and $\mathrm{Zr}-1.2 \mathrm{Nb}-0.3 \mathrm{Fe}$, respectively. And the hardness values were measured to be $186.9 \mathrm{Hv}$ and $214.7 \mathrm{Hv}$ for $\mathrm{Zr}-1.2 \mathrm{Nb}-0.28 \mathrm{Fe}_{2} \mathrm{O}_{3}$ and $\mathrm{Zr}-1.2 \mathrm{Nb}-0.43 \mathrm{Fe}_{2} \mathrm{O}_{3}$, respectively. It is apparent that the hardness increased with increase of iron and oxygen as shown in Table IV. The more rapid increase of hardness in $\mathrm{Fe}_{2} \mathrm{O}_{3}$ containing alloy is due to the presence of both oxygen and iron due to the reduction of $\mathrm{Fe}_{2} \mathrm{O}_{3}$.

Fig. 3 displays $\mathrm{Zr}-1.2 \mathrm{Nb}-0.2 \mathrm{Fe}$ (a) $\mathrm{Zr}-1.2 \mathrm{Nb}-0.3 \mathrm{Fe}$ (b) $\mathrm{Zr}-1.2 \mathrm{Nb}-0.28 \mathrm{Fe}_{2} \mathrm{O}_{3}$ (c) $\mathrm{Zr}-1.2 \mathrm{Nb}-0.43 \mathrm{Fe}_{2} \mathrm{O}_{3}$ (d) ingots processed by hot rolling. As shown in Fig. 1(a), $\mathrm{Zr}-1.2 \mathrm{Nb}-0.2 \mathrm{Fe}$ was rolled to $1 \mathrm{~mm}$ in thickness without cracking. In $\mathrm{Zr}-1.2 \mathrm{Nb}-0.3 \mathrm{Fe}$, edge crack started to propagate at the reduction ratio of $25 \%$. In $\mathrm{Zr}-1.2 \mathrm{Nb}-0.28 \mathrm{Fe}_{2} \mathrm{O}_{3}$, and $\mathrm{Zr}-1.2 \mathrm{Nb}-0.43 \mathrm{Fe}_{2} \mathrm{O}_{3}$, cracks appeared in the first pass of rolling. Fig. 3 clearly shows that the deformability of $\mathrm{Zr}$ alloys decreased with the addition $\mathrm{Fe}$ and $\mathrm{Fe}_{2} \mathrm{O}_{3}$.

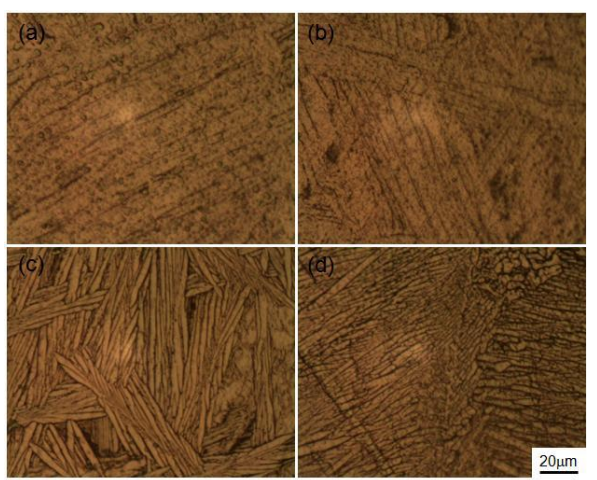

Fig. 2. Microstructures of the $\mathrm{Zr}$ alloys; a) $\mathrm{Zr}-1.2 \mathrm{Nb}-0.2 \mathrm{Fe}$, b) $\mathrm{Zr}-1.2 \mathrm{Nb}-0.3 \mathrm{Fe}$, c) $\mathrm{Zr}-1.2 \mathrm{Nb}-0.28 \mathrm{Fe} 2 \mathrm{O} 3$, d) $\mathrm{Zr}-1.2 \mathrm{Nb}-0.43 \mathrm{Fe}_{2} \mathrm{O}_{3}$.

TABLE IV: MICROHARDNESS OF THE ZR ALLOYS WITH FE OR $\mathrm{FE}_{2} \mathrm{O}_{3}$ ADDITION

\begin{tabular}{ll}
\hline & Hardness (Hv) \\
\hline $\mathrm{Zr}-1.2 \mathrm{Nb}-0.2 \mathrm{Fe}$ & 153.1. \\
\hline $\mathrm{Zr}-1.2 \mathrm{Nb}-0.3 \mathrm{Fe}$ & 167.8. \\
\hline $\mathrm{Zr}-1.2 \mathrm{Nb}-0.28 \mathrm{Fe} 2 \mathrm{O} 3$ & 186.9 \\
\hline $\mathrm{Zr}-1.2 \mathrm{Nb}-0.43 \mathrm{Fe} 2 \mathrm{O} 3$ & 214.7 \\
\hline \hline
\end{tabular}

In Fig. 4, SEM micrograph of the fracture surface and EDS spectra from the crack initiation site are exhibited. The fracture surface shows the typical cleavage fracture with river patterns. In general, the ductility decreases rapidly if the oxygen content exceeds $1800 \mathrm{ppm}$. In case the oxygen content exceeds $3000 \mathrm{ppm}$, the brittle facture typically occurs as shown in Fig. 4. The higher oxygen content revealed by EDS spectra from crack initiation site suggests that the higher oxygen content due to the reduction of $\mathrm{Fe}_{2} \mathrm{O}_{3}$ by $\mathrm{Zr}$ and dissolution of oxygen into matrix is responsible for the low deformability

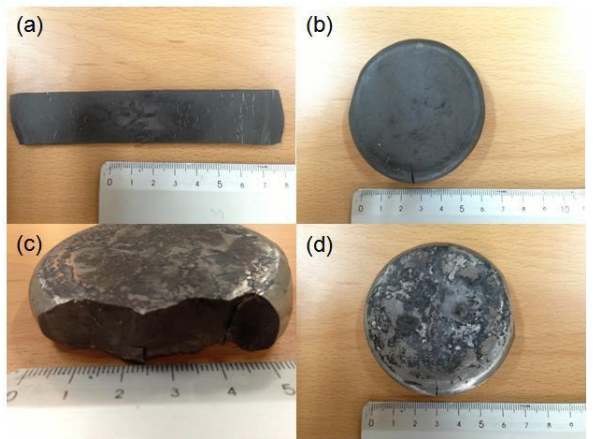

Fig. 3. $\mathrm{Zr}$ alloy ingots processed by hot rolling. a) $\mathrm{Zr}-1.2 \mathrm{Nb}-0.2 \mathrm{Fe}$, b) $\mathrm{Zr}-1.2 \mathrm{Nb}-0.3 \mathrm{Fe}$, c) $\mathrm{Zr}-1.2 \mathrm{Nb}-0.28 \mathrm{Fe} 2 \mathrm{O} 3$, d) $\mathrm{Zr}-1.2 \mathrm{Nb}-0.43 \mathrm{Fe}_{2} \mathrm{O}_{3}$.

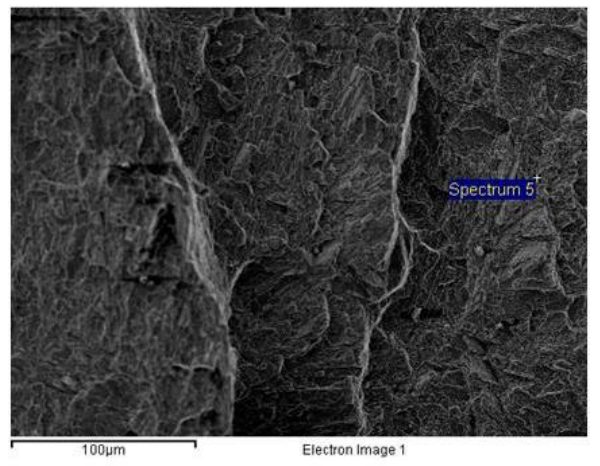

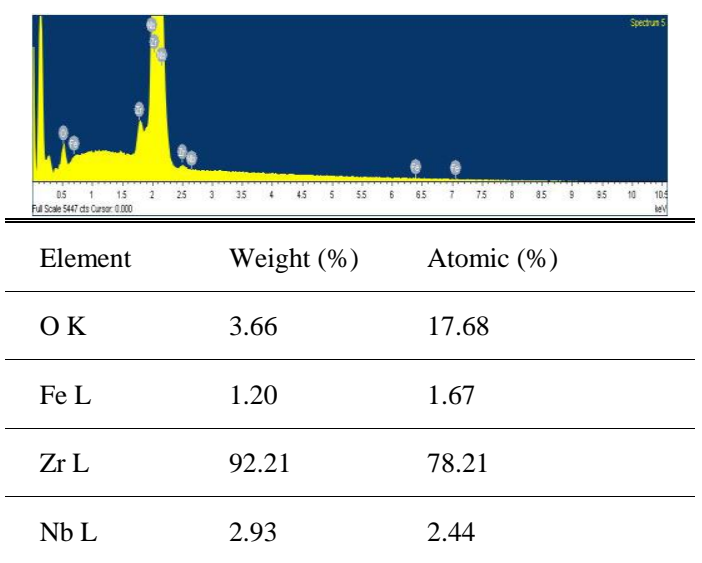

Fig. 4. Fractograph and EDX spectrum from crack initiation site of cracked $\mathrm{Zr}-1.2 \mathrm{Nb}-0.28 \mathrm{Fe}_{2} \mathrm{O}_{3}$ alloy during rolling.

Fig. 5 displays the stress-strain responses of cold-rolled(a) and annealed (b) $\mathrm{Zr}-1 \mathrm{Nb}-0.7 \mathrm{Sn}-0.1 \mathrm{Fe}$ alloy with the scrap:sponge ratios of 3:7, 5:5 and 7:3. It is interesting to note that the strength increases with increasing fraction of scrap, which can be attributed to the increase of oxygen content [11], [12]. The ductility decreased slightly with increase of scrap fraction. With annealing at $465^{\circ} \mathrm{C}$, the strength decreased and the ductility increased. Oxygen is known to impede the motion of dislocations and thereby increases the strength and decreases the ductility. 
One of the major current challenges in the nuclear energy industry lies in reducing maintenance and fuel cycle costs, while enhancing safety features [16], [17]. For application of $\mathrm{Zr}$ alloys cast with nuclear grade scrap, the strict controls of surface contamination by oxide and inclusion of iron oxide from scrap container are important [18]. The increase of oxygen content and oxide particles may deteriorate the deformability of $\mathrm{Zr}$ alloy ingots while they are processed into nuclear cladding tubes [14], [19]. The $\mathrm{Zr}$ alloy cladding tube's in-reactor behaviors such as mechanical strength and creep and irradiation-induced growth are mainly controlled by its alloying elements and impurities including oxygen and heat treatment conditions applied in the tubing processing [20], [21]. In the future works, the effects of alloying elements and particles on the tubing processing and creep properties [17], [19], [22]-[25] will be investigated for the safe application of nuclear fuel cladding tubes processed with $\mathrm{Zr}$ alloy ingots cast with nuclear grade scraps.
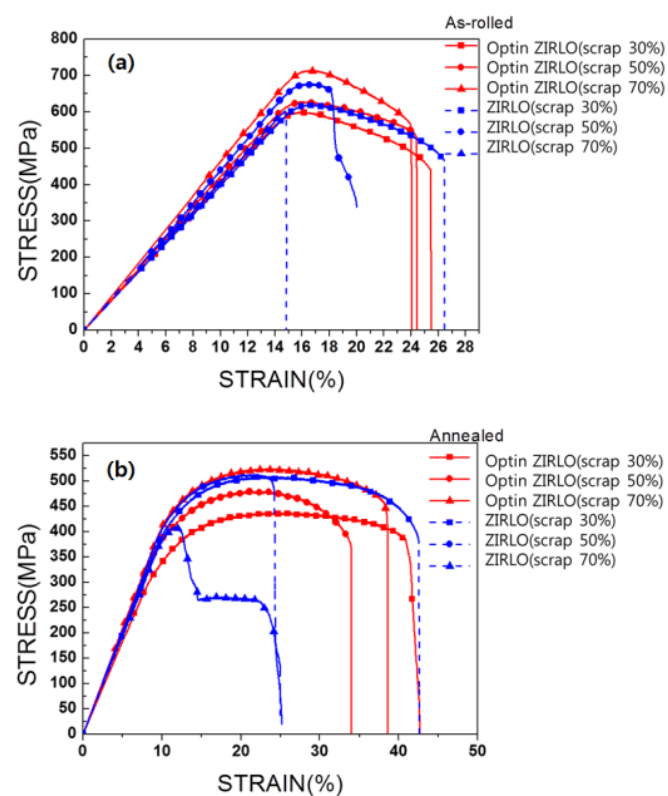

Fig. 5. Stress-strain curves of cold-rolled(a) and annealed(b) $\mathrm{Zr}$ alloys with scrap:sponge ratios of 3:7, 5:5 and 7:3.

\section{CONCLUSION}

In this study, the effect of the addition of $\mathrm{Fe}$ and $\mathrm{Fe}_{2} \mathrm{O}_{3}$ on the microstructure and deformability was studied and compared to the effect of scrap ratio on the mechanical properties of $\mathrm{Zr}-\mathrm{Nb}-\mathrm{Sn}$-Fe alloys. As a result of this study, the following conclusions were made;

1) In alloys with intentional $\mathrm{Fe}$ addition, plate-shaped $\alpha$ phase was observed whereas needle-shaped $\alpha$ phase was observed in alloys with $\mathrm{Fe}_{2} \mathrm{O}_{3}$ addition. The thickness of plate-shaped $\alpha$ phase in alloys with Fe addition was 8-10 $\mu \mathrm{m}$ whereas the thickness of needle-shaped $\alpha$ phase in alloys with $\mathrm{Fe}_{2} \mathrm{O}_{3}$ addition was observed to be $2-3 \mu \mathrm{m}$. The change of shapes of $\alpha$ phase is likely to be associated with the oxygen content in the alloys.

2) The hardness increased with increase of iron and oxygen in alloys with $\mathrm{Fe}$ and/or $\mathrm{Fe}_{2} \mathrm{O}_{3}$. The more rapid increase of hardness in $\mathrm{Fe}_{2} \mathrm{O}_{3}$ containing alloy is due to the presence of both oxygen and iron due to the reduction of $\mathrm{Fe}_{2} \mathrm{O}_{3}$
3) Oxygen content in the $\mathrm{Zr}$ alloy ingots increased rapidly with increasing fraction of scrap, which can be attributed to the surface oxide of scrap cake consisting of small pieces of turning, chips, etc. Iron content was not changed appreciably.

4) The fracture surface shows the typical cleavage fracture with river patterns. In general, the ductility decreases rapidly if the oxygen content exceeds $1800 \mathrm{ppm}$. In case the oxygen content exceeds 3000 ppm, the brittle facture typically occurred.

5) The strength increases with increasing fraction of scrap, which can be attributed to the increase of oxygen content. The ductility decreased slightly with increase of scrap fraction.

\section{CONFLICT OF INTEREST}

The authors declare no conflict of interest.

\section{AUTHOR CONTRIBUTIONS}

J.S.S. designed and performed the experiments and S.I.H. analyzed the data and wrote the paper.

\section{ACKNOWLEDGEMENTS}

This research was supported by the Future Material Discovery Program of the National Research Foundation of Korea (NRF) funded by the Ministry of Science, ICT and Future Planning (MSIP) of Korea(2016M3D1A1023532).

\section{REFERENCES}

[1] Nuclear Zirconium Alloy Market, Ux Consulting, Effect of Scrap: Sponge Ratio on Mechanical and Corrosion Properties of Zr-1Nb-0.7Sn-0.1Fe Alloy, 2010,

[2] Recycling - Metals U.S. Geological Survey Minerals Yearbook, Vanadium Recycling in the United States in 2004, 2003.

[3] S. Y. Lee, K. T. Kim, and S. I. Hong, "Circumferential creep properties of Zircaloy-4 and Zr-Nb-Sn-Fe cladding tubes," J. Nucl. Mater., vol. 392, pp. 63-69, 2009.

[4] S. Ko, S. I. Hong, and K. T. Kim, "Creep properties of annealed $\mathrm{Zr}-\mathrm{Nb}-\mathrm{O}$ and stress-relieved $\mathrm{Zr}-\mathrm{Nb}-\mathrm{Sn}-\mathrm{Fe}$ cladding tubes and their performance comparison," J. Nucl. Mater., vol. 404, pp. 154-159, 2010.

[5] J. M. Lee and S. I. Hong, "Design and mechanical characterization of a Zr-Nb-O-P alloy," Materials \& Design, vol. 32, pp. 4270-4276, 2011.

[6] K. W. Lee, S. K. Kim, K. T. Kim, and S. I. Hong, "Ductility and strain rate sensitivity of Zircaloy-4 nuclear fuel claddings," J. Nucl. Mater., vol. 295, pp. 21-26, 2001.

[7] K. I. Chang and S. I. Hong, "Effect of sulphur on the strengthening of a $\mathrm{Zr}-\mathrm{Nb}$ alloy," Journal of Nuclear Mater., vol. 373, pp. 16-21, 2008.

[8] S. I. Hong and K. W. Lee, "Stress-induced reorientation of hydrides and mechanical properties of Zircaloy-4 cladding tubes," Journal of Nuclear Mater., vol. 340, pp. 203-208, 2005.

[9] N. S. Gamba, I. A. carbajal-Ramos, M. A. Ulla, B. T. Pierini, and F. C. Gennari, "Zirconium alloys produced by recycling zircaloy tunings," $J$. Alloys and Compounds, vol. 578, pp. 553-558, 2013.

[10] S. I Hong, K. W Lee, and K. T Kim, "Effect of the circumferential hydrides on the deformation and fracture of Zircaloy cladding tubes," Journal of Nuclear Materials, vol. 303, pp. 169-176, 2002.

[11] B. Lee, J. Song, and S. Hong, "High-temperature deformability of a $\mathrm{Fe}-\mathrm{Cr}-\mathrm{Mn}-\mathrm{Ni}$ austenite stainless steel with high nitrogen and high carbon contents," Metals, vol.8, no. 608, pp. 1-14, 2018.

[12] J. Y. Ko and S. I. Hong, "Microstructural evolution and mechanical performance of carbon-containing CoCrFeMnNi-C high entropy alloys," J. Alloy. Comp., vol.743, pp. 115-125, 2018.

[13] S. I. Hong and H J. Kim, "Temperature dependence of elongation in Zircaloy-4," Materials Science and Engineering, vol. 86, 1987, pp. L1-L4. 
[14] S. I. Hong, W. S. Ryu, and C. S. Rim, "Thermally activated deformation of Zircaloy-4," Journal of Nuclear Materials, vol. 120, no. 1, pp.1-5, 1984.

[15] R. W. Cahn, P. Hassen, and E. J. Kramer, "A comprehensive treatment," Structure and Properties of Nonferrous Alloys, Materials Science and Technology, vol. 8, pp. 436-443, 1996.

[16] P. Rudling, R. Adamson, B. Cox, F. Garzarolli, and A. Strasser, "High burnup fuel issues," Nucl. Eng. Tech., vol. 40, pp. 1-8, 2008.

[17] G. B. Jeong et al., "Influence of microstructure modification on the circumferential creep of $\mathrm{Zr}-\mathrm{Nb}-\mathrm{Sn}-\mathrm{Fe}$ cladding tubes," Journal of Nuclear Materials, vol. 468, pp. 171-177, 2016.

[18] Y. K. Kim and S. I. Hong, "Influence of interface structure and stress distribution on fracture and mechanical performance of STS439/Al1050/STS304 clad composite," Materials Science and Engineering: A, vol. 749, 2019, pp. 35-47.

[19] S. Ko, S. I. Hong, and K. T. Kim, "Creep properties of annealed $\mathrm{Zr}-\mathrm{Nb}-\mathrm{O}$ and stress-relieved $\mathrm{Zr}-\mathrm{Nb}-\mathrm{Sn}-\mathrm{Fe}$ cladding tubes and their performance comparison," Journal of Nuclear Materials, vol. 404, pp. 154-159, 2010.

[20] E. F. Ibrahim, R. Choubey, and J. J. Jonas, "Effect of texture and heat treatment on high temperature deformation of Zircaloy-2," J. Nucl. Mater., vol. 126, p. 44, 1984.

[21] R. A. Holt, "Mechanisms of irradiation growth of alpha-zirconium alloys," J. Nucl. Mater., vol. 159, p. 310, 1988.

[22] Y. B. Kang, S. H. Shim, K. H. Lee, and S. I. Hong, "Dislocation creep behavior of $\mathrm{CoCrFeMnNi}$ high entropy alloy at intermediate temperatures," Mater. Res Lett., vol. 6, pp. 689-695, 2018.

[23] K. H. Lee, S.-K. Hong, and S. I. Hong, "Precipitation and decomposition in $\mathrm{CoCrFeMnNi}$ high entropy alloy at intermediate temperatures under creep conditions," Materialia, vol. 8, p. 100445, 2019.

[24] M. Zahoor, "Modeling primary creep for Zircaloy claddings during load reversals and drops in BISON," Journal of Nuclear Materials, vol. 511, pp. 212-219, 2018

[25] T. Narukawa et al., "Experimental and statistical study on fracture boundary of non-irradiated Zircaloy-4 cladding tube under LOCA conditions," Journal of Nuclear Materials, vol. 499, pp. 528-538, 2018.

Copyright $\odot 2020$ by the authors. This is an open access article distributed under the Creative Commons Attribution License which permits unrestricted use, distribution, and reproduction in any medium, provided the original work is properly cited (CC BY 4.0).
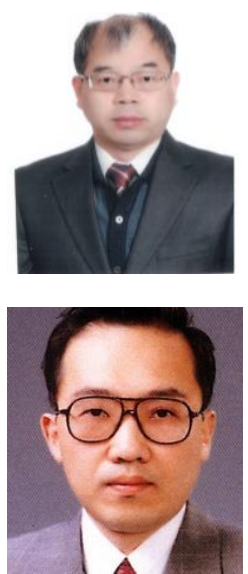

Korea.
Jae Sook Song obtained a doctoral degree of materials science and engineering from Chungnam National University in 2000. He worked as a researcher in Korea Atomic Energy Research Institute and Jeonnam Techno-Park since then he is currently a senior research associate in the Nano Engineering Research Center of Chungnam national University, Korea.

Sun Ig Hong obtained a doctoral degree of materials science and engineering from University of Pennsylvania, USA, He worked as a researcher in Korea Atomic Energy Research Institute and Los Alamos National Lab. He also worked as a visiting professor at University of Michigan. He is currently a professor in the Department of Materials Science and Engineering of Chungnam National University, 